\title{
Julian Murphy
}

\section{Adding to the hall of mirrors: A fictocritical response to Anthony Macris' Great Western Highway}

\author{
Abstract \\ In this essay I take, as my departure point, Anthony Macris' 2012 novel Great \\ Western Highway: a love story. My specific focus is the presence of technology \\ in the novel, and the way technology is shown to shape relations between \\ individuals and between the individual and the world. Rather than adopt a \\ strictly critical mode of writing, I have chosen to write this essay by oscillating \\ between critical and creative prose, and drawing on a mixture of academic \\ research, personal experience and anecdote. Such a mode is invited by Macris' \\ novel, which itself occupies the liminal space between fictional and critical \\ writing. Furthermore, the fictocritical format of this essay allows me to \\ deliberately confuse and conflate my own images with those from Macris' \\ novel. I enact this confusion in the hope that my essay becomes a contribution \\ to Macris' textual hall of mirrors, or what he more technically labels the \\ 'Generative mise en abyme' (Macris 2008: 2). \\ Keywords: fictocriticism, technology, Anthony Macris
}

\section{Prologue}

Sitting, staring at my laptop screen the first question I must answer is 'how should I write about the presence of technology in Anthony Macris' Great Western Highway?' But as my mouse moves to italicize the last three words of the previous sentence, I realise that I had already partially answered the question before I posed it. By choosing to 'write' about Great Western Highway on a computer, I have chosen to write from within the phenomenon the book seeks to examine - society's saturation with technology, especially digital technology.

This saturation is so complete that I can't turn anywhere anymore without being reminded of the penetration of digital technology into every aspect of my life. Even the old-fashioned, hard copy Oxford English Dictionary, which sits at a hostile distance from the laptop on my desk, provides no escape from technology as it directs me to new and expanded definitions on its website: www.askoxford.com/oec. Moments ago, ignoring the direction to the website, I rested the hefty tome in my lap and flipped to the entry for 'prologue':

prologue $n .1$ a separate introductory section of a literary or musical work. 2 an event or action leading to another. (Soanes \& Stevenson 2008: 1148) 
Which is exactly what these words are intended to be, a prolegomenous textual event leading to the 'Main Event' in which I will engage in some real literary criticism. But a characterisation of the Main Event as real literary criticism begs the question of what the hell this is, that I am writing right now, if it's something other than literary criticism. 'Creative nonfiction,' apparently. Or, more specifically, 'fictocriticism'. I wish I could leave it at that. I wish I could assume that all my readers had heard of, and approved of, the fictocritical mode of writing. But the reality is that many readers have never heard of fictocriticism, and those that have consider it a nebulous concept or 'doubtful category' (Kerr 1996: 94).

So I had better contextualise. Fictocriticism came to prominence in the 1970 s as a way of writing outside the patriarchal structures of academic discourse; Hélène Cixous, Luce Irigaray and Monique Wittig are commonly cited as the most prominent of its early practitioners (Gibbs 2005). This is not to say that writers had not been writing fictocritically before the 1970s, just that no distinct genre had been articulated to encompass these writings. Today the genre is not so strictly associated with feminist projects and the label is commonly applied to any literary writing that combines creative and critical elements (Gibbs 2005). It is on the basis of this more inclusive definition that I bring my own writing within the category of fictocriticism.

There is sub-category of fictocriticism that has always attracted me, and one that I hope to bring this essay within - I am referring to the fictocritical review essay. Such pieces of writing respond to a specific artwork, film or literary text by melding personal reflection, fiction, and critical comment. I first came to this form of writing through a rather atypical example, Michel Foucault's essay on Diego Velázquez's painting, Las Meninas (Foucault 2002). In this anomalous composition, Foucault refuses to adopt the traditional mode of art criticism that would have required him to write objectively and historically (Greslé 2006: 223). Instead, Foucault writes with creative abandon, not only describing the painting but also speculatively adding to its story.

This is the sort of critical writing that really captures me, writing that not only describes its subject but also adds to it. I like the idea that the critic need not be a passive observer but can reframe or even refashion the original text by providing further creative material. Another of my favourite examples of this sort of writing, this time from closer to home, is Elizabeth MacFarlane's fictocritical memoir/essay on JM Coetzee's 2003 book Elizabeth Costello (MacFarlane 2011). Like Foucault, MacFarlane is not afraid to confuse her own voice with Coetzee's and to supplement Coetzee's fiction with further scenes of MacFarlane's own devising. MacFarlane dilutes, or even pollutes, Coetzee's text. In doing so she adds to the narrative volume of the original text, expanding it so that its tide of influence may lap against distant shores it otherwise may never have touched upon.

To me, Great Western Highway seems to invite just this sort of response from me. This is because Macris' narrative needs to be brought up to date with additional creative material that reflects the changes in technology since the mid 1990s, when the novel is set. I am perfectly placed to provide such an addendum. This is because I am the contemporary equivalent of Macris' 1990s protagonists. Like the characters in the novel I am a twenty-something, living in an Australian city and trying to figure out how to forge and maintain meaningful interpersonal relationships without technology getting in the way. In a world fast being overrun by technology I am stubbornly holding on to my hard copy dictionary and my early 2000 s brick of a mobile phone, while refusing to allow a TV inside my house. I am one of the few people in my social circle without Facebook, Twitter, Instagram or Tinder, and I am 
concerned about the way these technological developments are changing the way we relate to the world and each other. It's this commonality of context that justifies my supplementing the fictional content of Great Western Highway with my own experiences, reflections and anecdotes.

But enough justification for now, before I interrupted myself I was looking up the entry for 'prologue' in my dictionary. An act, by the way, which admittedly takes longer than using the dictionary application on my laptop but which requires a physical effort which turns my mind more concertedly to focus on the meaning of the searched-for word. So now, having used my hard copy dictionary rather than its digital avatar, I have the luxury of scanning the words surrounding 'prologue' on the page dedicated to all meanings lying between 'prolactin' and 'prominence'. And I don't have to go far to find something that will make a neat little prologue to my later comments on digital technology and communication. Immediately preceding 'prologue' in my dictionary is the following entry:

Prolog n. computing a high-level computer programming language first devised for artificial intelligence applications. (Soanes \& Stevenson 2008: 1148)

Which is exactly not what these words, my words, are intended to be. These words are intended to be as devoid of technology as possible. I had hoped the words of this prologue would constitute a personal communication between me and you, my reader, without technological mediation. Actually, let me qualify that, I'm not so naïve. I know it's not as simple as that anymore communication is almost always mediated by digital technology. I'm not speaking these words to you, instead I'm alone in my room staring at a screen and pressing keys on a computer and you could be anywhere in the world staring at a different screen, your eyes picking out from the many-coloured pixels the words which my computer allowed me to write, or more accurately, type.

And so I tap at the keyboard of my MacBook Pro ${ }^{\mathrm{TM}} 15.4$ - a computer incomparably lighter, sleeker, and faster than the one upon which Macris composed his novel in the late $90 \mathrm{~s}$ - and these words materialise on my 'retina display'TM screen with a clarity of which Macris could not have dreamt. And while I stare at my blinking cursor my gaze is also taking in the other program windows I have open, and the stock background image of the Andromeda Galaxy, and the strip of icons running along the bottom of the screen. And from time to time a window pops up asking me whether I want to download the latest software upgrades from the internet. And my Spelling and Grammar application tells me that the word 'internet' in the previous sentence should be capitalized. But I don't take my cursor back to the ' $\mathrm{i}$ ' and make it an 'I' because I'm of the opinion that Spellcheck ${ }^{\mathrm{TM}}$ has got it wrong this time. So I retain the ' $\mathrm{i}$ ' because even in these early stages of writing, I know I want to object to technology's attempts to dictate the way I interact with others. Which isn't to say that I am advocating for a wholesale rejection of technology. I accept the utility of technology in certain circumstances to facilitate and enhance communication between individuals. Technology, specifically email, allowed me to get in touch with Macris prior to writing this piece and get my (virtual) hands on some of his academic writing on technology and alienation. What I am arguing for is a self-awareness regarding the extent to which technology governs our everyday life. If this is to be my contention I may as well start by writing in the way Iwant to rather than the way in which Spellcheck ${ }^{\mathrm{TM}}$ would have me write. 
But I have been distracted from my original task, which was really to ask and answer the question: 'how should I structure a fictocritical comment on the presence of technology in Great Western Highway?' The structure I am most attracted to is that which Macris himself adopts in his novel, and which he expands upon in the author's note at the end of the novel proper. In this exegetical bookend to the fictional text Macris discusses the literary structure which he calls the 'Generative mise en abyme' (Macris 2012a: 343). This structure involves deploying, in the text, a matrix of images and reflections which do not immediately adhere to the traditional hierarchy of image $v s$. real. A text employing the Generative mise en abyme collapses the framework by which the reader differentiates between the image and the reflection. What results is a text within which 'there are so many mirror texts that the hierarchy between frame and miniature implodes, and the text becomes an open field of signs rather than something organised according to the logic of frame and miniature' (Macris 2012a: 343). The reason Macris wants to write a novel in this form is that he hopes the experience of reading it will mimic the experience of living in the image-saturated world of today. If I've lost you here just think of Macris' novel as a hall of mirrors - that pretty much gets at the essence of the Generative mise en abyme.

What I want to do in my essay is to add to Macris' hall of mirrors, and the most effective way to do so seems to be by writing my response fictocritically. While conducting an academic critique of Macris' text I will also be quoting, reproducing and remoulding his fictional images within my critical text and supplementing them with my own auto-fictional image interjections. Thus my essay will construct its own disorientating field of images drawing from the novel and my own life. A critical text is typically a frame through which a reader can approach a fictional text. But I'm not going to offer such a reliable frame of reference. My essay will collapse the distinction between critiqued and critiquing text, it will be neither a pure reflection on Macris' text nor an image in its own right. Rather, my essay will interpenetrate with Macris' novel; I will be reproducing and adding to the field of images Macris has constructed, adding a few more mirrors to the hall.

\section{A hall of mirrors: the presence of technology in Anthony Macris' Great Western Highway: a love story (2012)}

... a long title but one true to the tone of Macris' novel, which is written with workmanlike semiotic precision, a precision which suggests Macris' desire to write technically, to write in a manner befitting an age in which words are increasingly thought of as units of meaning and language a mode of recording data, in which 'Prolog' precedes 'prologue' in the dictionary, in which digital dictionaries have replaced print dictionaries...

The single most important phenomenon of contemporary times, according to Anthony Macris, has been 'the rise of digital technologies' (Macris 2012a: 341). The impact of these technologies on the life of the individual is illustrated in Macris' most recent novel, Great Western Highway: a love story. In this novel technology is shown to be dictating the way the individual relates to others and the way the individual understands, and relates to, the world around them. This essay begins by examining the ways in which the novel shows technology to be mediating relations between individuals. It will be posited that individuals in the novel become increasingly distracted from their face-to-face interactions with each other by the presence of technology in their lives. The presence of the video screen in a number of scenes in Great Western Highway will be read as a paradigmatic instantiation of this phenomenon. In the second 
part of this essay Macris' novel is analysed for the way it understands technology to be governing the individual's relation to the world. This essay argues that the novel shows the proliferation of images in the technological age to be undermining the individual's ability to distinguish between the image and the real. Jean Baudrillard's theory of simulation is drawn upon, but distinguished, in this regard. It will be suggested that the individual's increasing engagement with the image rather than the real leads to heightened feelings of disempowerment and alienation in contemporary society. To conclude, this essay will conduct a reading of the novel's final scene to suggest that Macris offers love, or direct emotional engagement with others, as a way to mitigate the alienating effects of technology on one's relations to other individuals and to the world more generally.

\section{Technology mediating relations between individuals}

Macris has said that Great Western Highway is about 'love and capitalism' (Macris 2012a: 335) but he could just as easily have chosen 'technology' as the second term in the dyad. The novel is centrally concerned with exploring the quality and dynamics of human interactions in the digital age. To this end, Macris constructs the interactions between his two romantically linked protagonists - Nick and Penny - in environments saturated with digital technology, or products of this technology. The most common object present during these interactions is a television screen. When Nick visits Penny a month after their break-up the television is turned on, and up, throughout their pre-dinner conversation. As the reader watches Nick and Penny acting out the narrative of preparing the meal, a miniature narrative unfolds in the background of the vignette - the television plays a cooking show in which the host enacts the preparation of another meal (Macris 2012b: 124).

...This is me reflecting an image from Macris' novel in my responsive text - the beginning of my contribution to Macris' hall of mirrors. By re-presenting this scene in my text I am fulfilling the generative element of Macris' novelistic mise en abyme - Macris' original scene has generated a mirror scene in my text. This particular scene is especially appropriate for re-presentation because it already contains a reflective dynamic inside it - the relationship between the televised narrative and Nick and Penny's narrative. By drawing your attention to this scene without directly quoting the novel I am also problematising the distinction between mirror and original. Is my scene simply a re-presentation of Macris'scene or has it become its own textual moment? Are critical texts even allowed to generate their own narrative moments or must they always be subordinated to the progenitor literary text? These questions, which arise from the very structure of my fictocritical response, mirror the questions posed by Macris concerning the changing hierarchy of image and original which I alluded to in the Prolog, sorry, prologue.

And another thing which I would have you note is that when I am replaying the scene from Macris' novel I am deploying a visual vocabulary. This is the reason why I have chosen to describe the reader as 'watching' Nick and Penny in the kitchen, and my Nick and Penny are 'acting out' a 'vignette'. What I am attempting to do here is to construct a parallel between the reception of narratives through visual images, e.g. watching $T V$, and the reception of narratives through written words, e.g. reading a novel. This is something that Macris does not advert to. While bemoaning our bombardment with visual narratives through television and advertising, Macris makes no note of the fact that digital technology has also increased our exposure to written narratives. While some of us still read traditional books, print magazines and newsprint, 
these sources of written narratives have been supplemented, and perhaps overtaken, by e-books, e-news, online magazines, blogs, forum threads, emails, and text messages. (Incidentally, the publication of Great Western Highway itself illustrates this generative spread of written narratives as a result of technology. On the penultimate page of the print edition of the novel the publisher announces that it is 'proud to reissue Anthony Macris' first novel, Capital: Volume One, as an ebook. Please check our website for details at www.uwap.com.au'.) In Great Western Highway, Macris seems to be suggesting that our over-exposure to, and passive reception of, image narratives in today's world is resulting in us having less time for the creation of our own narratives through our interaction with other people. But why not include written narratives in this analysis? Reading a book or newspaper on the train to work is just as anti-social as watching an episode of something on your tablet.

But of course we don't want to include written narratives in our analysis, do we, because we like books, books must be better for society than TV and advertising. But why? The answer, for me at least, is in the fact that the content of written narratives are often more substantial, more intellectually and emotionally challenging, than the content of visual narratives (pulp fiction and trashy magazines immediately present themselves as exceptions to this general rule). If I am right, then what Macris should really be lamenting is not that digital technology has allowed for an exponential increase in image narratives but that so many of these narratives are superficial and a distraction from our interactions with other people. And perhaps Macris should be a bit more evenhanded and acknowledge that digital technology has also allowed for a wider circulation of some narratives of substance like his out-of-print first novel.

But with my phone turned off and my wi-fi disabled I am on a bit of a roll here and this auto-fictional-distinguished-by-italics tangent is threatening to get away from me, to morph into something which it's not allowed to be, it's threatening to get too critical and thus only nominally different from my unitalicised hard-core literary criticism...

The incessant 'babble' (Macris 2012b: 125) of the television excuses Nick and Penny from engaging in any meaningful conversation, or talk, instead they just 'chat' (125).

...I know I should get on with the 'criticism' but this is too good an opportunity to miss. Babble. When I read this scene in the novel and saw the word 'babble' I couldn't help wanting it to be 'Bable'. And why not? Both are derived from the same etymological root 'babbelen' (of Mid. Low. Ger. origin I am told by my trusty hard copy dictionary) which itself is thought to be a reference to the variety of 'ba' noises that children make before they can form words. So I am now reading Babel instead of babble and Macris' sentence becomes a comment on television as a postlapsarian common language - the one unifying element of our globalised, multicultural world. But a stunted language, a language of infants infinitely repeating, or reproducing, variations on a theme. Which again leads me to the conclusion that what Macris is really concerned about is the quality of the content of image narratives rather than the mere fact of their proliferation...

It is only when the television is silent for a few seconds that Nick and Penny are forced to acknowledge the real silence between them - the lack of any meaningful communication. In this moment of silence the television retreats from the scene, technology suspends its mediation of human relations. As Nick and Penny stand facing each other in silence the basic conditions for 
meaningful interaction are finally established. The narrator then intrudes and flags the fact that 'now, it seemed, it was time to talk' (Maris 2012b: 125).

...not babble, or chat, but talk...

It is hard to read this scene in any way other than to be lamenting the manner in which human interactions have been diluted by technology - made less immediate, less involved, and less intense by an ever-present technological interface.

... a term, 'interface', which incidentally has a specific meaning in computing: 'a device or program enabling a user to communicate with a computer, or for connecting two items of hardware or software'. Yep, dictionary again, hard copy...

The other context in which technology is repeatedly portrayed to be diluting human interactions in the novel is in conversations over the telephone.

Tellingly, the only time when the television is turned off during Nick's visit to Penny's house is when the host is speaking on her landline telephone (Macris 2012b: 128).It is not revealed to Nick who Penny is speaking to during this conversation, or what she is talking about, but the reader knows that it is Murray on the end of the line - another ex-lover of Penny's. The telephone thus allows Penny to simultaneously conduct separate conversations with two rivals for her attention and love, all without revealing the fact to either of them. In this scene technology is shown to be facilitating an insensitive act of dialogical infidelity on Penny's behalf. Nick is a victim of this telephone-facilitated infidelity, or insensitivity, at another time in the novel when his partner of nine years ends their relationship with a phone call (211). The telephone, like the screen, is shown to be contributing to the breakdown of sincerity in human interactions.

...I can't help noting here that Macris' novel has dated. Originally written in the late 1990s, and set in 1996, the novel's illustrations of technology mediating our lives appear prehistoric in today's world. Nobody uses landlines in Australia anymore do they? At least not the young urban demographic Macris is writing about. And email, which only gets a brief cameo in Macris' novel, has combined with text messaging and social media to make written communication at least as popular as spoken. If anything, though, these developments conform to the trajectory that Macris identified in his novel. Now, not only do people regularly interrupt conversations to answer phones but I can't even seem to have a meal with anyone without them simultaneously conducting parallel conversations by text on their smartphones...

\section{Technology mediating the individual's relation to the world}

Technology's influence on the life of the individual is not restricted to the social sphere in Macris' novel. In fact, the novel is equally concerned with illustrating the ways technology is reshaping the individual's relation to, and understanding of, the world around them. The novel shows technology to have produced 'a world saturated with idealised and contradictory images [and image narratives]' (Macris 2012a: 337). This proliferation of images, the novel seems to suggest, is eroding the individual's confidence to negotiate his or her way through life in contemporary society. As individuals increasingly engage with image narratives rather than real people, Macris shows them becoming alienated from the people and events of the real world. 
The most significant source of images in the novel is advertising. As Nick walks along Parramatta Road towards Penny's house he is subjected to a stream of advertising images. The largest of such images are two huge billboards advertising men's and women's underwear, positioned on opposite sides of the road as if in dialogue with each other. Smaller posters line the road advertising products and services of local businesses (Macris 2012b: 26-27). Above the footpath signs dangle from shop awnings (14). The shopfronts abutting the footpath constitute what Macris has called 'a continuum of advertising signs' (Macris 2008: 13). Behind the shopfronts lie elaborate window displays each constituting its own carefully constructed advertising image (Macris 2012b: 1819). Inside the shops, video screens play promotional material on permanent loop for the benefit of passers-by (23).

This incredible visual montage - spanning almost forty pages in the novel illustrates the density of image narratives in contemporary society. In such an environment individuals become powerless spectators, passive 'consumers of narratives' (Macris 2012a: 342) with no direct involvement in the creation of such narratives. Each advertising image constitutes an injunction directing the individual to act or think in a certain way (Macris 2008: 13). Technology, Macris seems to be suggesting, is changing the way the individual exists in the world, undermining their agency and entangling them in a web of idealised images and reflections which they increasingly take to be the 'real world'. In this aspect of his narrative Macris is indebted to Jean Baudrillard, who is duly referenced in the list of sources at the back of Great Western Highway. Baudrillard's theory of simulation holds that the image, or the simulacrum, has become the real. Thus Baudrillard writes that ' $[\mathrm{in}]$ the age of simulation ... it is no longer a question of imitation ... [i]t is rather a question of substituting signs of the real for the real itself' (Baudrillard 1988b: 167). On Baudrillard's account, society now exists in a 'hyperreal' made up of matrices of simulacra without any origin in what was traditionally viewed as 'reality' (Baudrillard 1988b: 166-167).

Macris, however, does not go so far as Baudrillard. In fact in his extra-fictional writing Macris has been keen to distinguish his position from that of Baudrillard (Macris 2008: 12). Instead of endorsing Baudrillard's idea of the hyperreal, Macris describes increasingly intricate and extensive systems of simulacra interpenetrating the real. Macris' key departure from Baudrillard, then, is that in Great Western Highway images maintain some connection, causal or productive, to the real. In the case of advertising images, Macris holds that 'enunciation becomes a kind of production, but more than just textual production in the linguistic sense' (Macris 2008: 10). Advertising images, Macris argues, can have consequences in the sphere of the real. The most obvious of these consequences being when an advertising image causes an individual to act in a certain way by buying something, dressing differently or acting differently. This is most obviously instanced in the novel when Penny looks out of her office window and sees a billboard of a woman in lingerie. The sight of the image initially causes Penny to resolve to treat herself to a pair of the advertised underwear. For Macris, the world of simulacra is a world of images which exerts causal forces on the world of the real but does not supplant or replace the real as occurs in Baudrillard's account.

Macris also addresses the effect of technology on the everyday life of the individual in the novel's use of the Generative mise en abyme. The Generative mise en abyme is a literary form that incorporates a profusion of images and reflections, thereby attempting to undermine the hierarchy between reflection and original such that the veracity of both is equally in question. Macris employs this model in his narrative in an attempt to textually mimic the experience of living in contemporary society, which he believes 'can be seen as 
one vast generative mise en abyme' (Macris 2008: 8). The societal Generative mise en abyme can be read as Macris' watered-down version of Baudrillard's hyperreal. In Macris' societal Generative mise en abyme the proliferation of the image has been precipitated by developments in digital technology, particularly the technologies which allow us to construct images - photography and film and circulate those images - print technology, screen technology, and the internet. These technologies have allowed for the fast and effective creation and publication of images of ourselves, images that are often highly constructed and idealised. In his textual use of the Generative mise en abyme Macris wants the reader to feel the alienation and disorientation that the dizzying play between image and real causes in the contemporary citizen.

...A little anecdote here to leaven all the theory: a few weeks ago I was at an exhibition of photographic and video works at one of our big public galleries, and I encountered an artwork perfectly instantiating Macris' idea of the Generative mise en abyme. The work was allocated a room entirely to itself. On entering the room I spied a video screen on the far wall which I presumed to be showing the artwork. As I approached the screen I realised that the video on display was real-time footage, shot from one of the top corners of the room, of myself walking towards the video screen. Standing there viewing myself viewing myself, ad infinitum, I could not confidently draw a line to separate the artwork from reality. I wanted the visual images on the screen to be the entirety of the artwork. But I had to acknowledge that it was just as plausible that the artwork encompassed the entire room: the physical space in the room, my corporeal being, the camera filming me, the monitor showing the footage, and the images playing on the monitor...

One illustration of the Generative mise en abyme in Macris' novel is the image of Nick looking up from the deserted footpath of Parramatta Road at a billboard displaying an image of a woman in lingerie. Nick stares up at the idealised woman. But the billboard-woman does not return Nick's stare; instead her gaze is directed over Nick's head to where another billboard displays an image of a man in designer underwear (Macris 2012b: 49). This is a disorientating moment, not only for Nick but also for the reader. In the lead-up to this scene Nick has been the framing character for the narrative, the reader has been inhabiting Nick's character. But at the moment when the billboardwoman ignores Nick's gaze, the focal frame of the narrative is questioned and the reader is forced to acknowledge that, at least in the novel, the billboardwoman can have just as much agency as any other fictional character, Nick included. The distinction between the 'real' and the 'image' in the narrative dissolves. While reading this passage the reader feels something of the disorientation that Macris is suggesting all individuals feel in the imagesaturated world of the societal Generative mise en abyme. In this imagesaturated world society has not lost all connection to the real, as Baudrillard would have it (Baudrillard 1988b: 167), rather the real is becoming increasingly difficult to distinguish from the simulacra.

...to interject here and bring Macris up-to-date I want to direct your attention to the recent phenomenon of guerrilla advertising. I'm sure you've heard all about this because I have, and I'm usually the last person to catch onto these things. But in case you live under a bigger rock than me I'll sketch out what I mean by guerrilla advertising. The most common example is that a short video, purporting to be a home movie, will get posted on YouTube or Vimeo or whatever. The video will usually have normal-looking people playing basketball or skateboarding or engaging in some sort of practical joke. The video will gain momentum on-line and soon be registering millions of views and it's only then that viewers begin to notice that all the people in the video happen to be wearing the same brand of clothes... 
A further example of the novel's use of the Generative mise en abyme is the detailed recounting of the events of a film Nick and Penny are watching. Another is the reproduction, on the scale of a full page, of a poster advertising home loans which Nick sees while walking along Parramatta Road. When reading these passages the reader is, in a sense, looking at an image of a real original - The Fifth Element is a real film and the poster Macris reproduces in the novel may well be a real poster. For a moment these images escape their fictional framework and become real for the reader. What Macris is attempting to do with this disorientating matrix of images and reflections is to make the novel, like contemporary society, 'a locus of increasingly complex information flows' (Macris 2008: 22). In such a world, Macris suggests, the individual is liable to feel distanced from other human beings and real events. After Nick has watched hours of footage of the Gulf War on television the narrator comments: 'Never before ha[d] ... [he] felt so close to history, yet so irrelevant to it' (Macris 2012b: 254). This is because advertising and media images only flow one way, allowing passive reception but not response from the individual viewer. In fact, Baudrillard has characterised the media image as that which 'forbids response' (Baudrillard 1988a: 208). The result of this phenomenon is that individuals in the societal Generative mise en abyme feel themselves to be simply an intersection point for various vectors of digitally-produced image narratives, only tenuously linked to the real.

\section{A reading of the novel's final scene - how to love in the world of technology}

Despite the discussion above, Great Western Highway does contain a small kernel of hope for the individual in the rapidly advancing technological age. This hope resides in the continuing possibility for emotionally engaged interaction between individuals. In the closing pages of the novel, Penny desires 'something very simple, something without a past, without layers. It was the simple joy of talking to someone you loved' (Macris 2012b: 307). Direct talk between emotionally engaged individuals is put forward as a positive alternative to technologically mediated interactions. The fact that Macris adopts the second person address in this closing chapter leaves the reader in no doubt that he is proposing engaged communication as not just a salve for his characters but also for individuals in society at large. But is such talk even possible in a world saturated with technologically produced image narratives, always threatening to distract the talker? Macris seems to suggest that the answer is 'yes', that one can talk over the distractions. The novel closes with Nick and Penny standing, mostly silent, in front of a car dealership with a small video screen playing an advertisement for the Lamborghini Diablo. The screen successively projects images and words directing its viewers to feel a certain way about the product it is promoting. The words 'passion' and 'commitment' vie for Nick and Penny's attention. But Nick and Penny mostly ignore the screen, they are engaged in an immediate and emotionally significant interaction between themselves. It is as if Nick and Penny have adapted to the technology saturated world, they have learnt to live and 'talk' in the company of screens without allowing their life or talk to be determined by what is on the screen.

But there is a complicating factor in this final scene. As Nick and Penny stand in front of the car dealership their silhouettes are reflected in yet another screen - the windscreen of a Lamborghini Diablo in the showroom. It is tempting to read this screened image as another in Macris' series of imperfect and disorientating reflections - another mirror in the hall of mirrors that is contemporary life in the technological age. But such a reading would be 
reductive. The screen which holds the image of Nick and Penny is not an animated one, it can only reflect what stands in front of it, its generative power is derivative. And although the screen reflects imperfectly - capturing only an outline of the couple, their silhouettes - Nick and Penny control the content of the reflection. Accordingly, one might read this scene as asserting the agency of the individual to determine the extent of their engagement with the screened image.

This assertion of individual agency is not absolute; the individual must still accept the presence of the screen, the presence of technology, and learn to live with it. Macris has written '[i]t's a curious type of belonging, this belonging to urban spaces that are constantly being altered by ... technological change' (Macris 2012a: 338). Nick and Penny cannot deny the existence of the screens in the final scene. Nor can they deny that their interactions are always, to some extent, going to be affected by the proximity of technology. The task of the individual, Macris seems to suggest, is to negotiate as best they can for direct engagement with other individuals. Such a negotiation is illustrated in the final scene in front of the car dealership, when Nick asks to see a photograph of Penny as a child. This request signifies an acceptance that technology and the image - here the camera and the photograph - are a part of contemporary social interaction. At the same time though, Nick's request is a meaningful and an emotionally charged one, an assertion that one can still strive for immediacy and directness in human relations in amongst all the images and screens.

...When I first finished the novel I didn't really know what to make of it, but the final image stuck with me, the image of a couple looking at their own reflection in a windscreen. And so I thought it a suitable way to finish my response. I have repeatedly reproduced and adapted Macris' images throughout this essay in an attempt to contribute to his textual Generative mise en abyme. And so I will add another reflection to this final image. Instead of Nick and Penny looking at an image of themselves in the windscreen, picture yourself in their position. In this chapter of the novel Macris uses the second person address for only the second time in its three hundred odd pages. Macris is inviting you and me, as readers, to self-reflect. So the narrative text collapses as a frame and the characters are no longer safely fictional. Instead it is you and me standing next to each other, silent, in front of the car dealership. Imagine the scene: you and I looking at an image of ourselves staring back at us.

\section{Works cited}

Baudrillard, J 1988a [1985] 'The Masses: The Implosion of the Social in the Media', trans M Maclean, in M Poster (ed) Jean Baudrillard: Selected Writings, Stanford University Press, Stanford CA return to text

Baudrillard, J 1988b [1981] 'Simulacra and Simulations', trans P Foss, P Patton and P Beitchman, in M Poster (ed) Jean Baudrillard: Selected Writings, Stanford University Press, Stanford CA return to text

Foucault, M 2002 [1966] 'Las Meninas', trans AM Sheridan Smith, in M Foucault The Order of Things: An Archaeology of the Human Sciences, Routledge, London return to text

Gibbs, A 2005 'Fictocriticism, Affect, Mimesis: Engendering Differences', TEXT 9, 1 (April): http://www.textjournal.com.au/april05/gibbs.htm (accessed 9 May 2013) return to text

Greslé, Y 2006 'Foucault's Las Meninas and Art-Historical Methods', Journal of Literary Studies 22: 211-228 return to text

Kerr, H 1996 'Fictocriticism, the "Doubtful Category" and "The Space Between"”, in C Guerin, P Butterss \& A Nettlebeck (eds) 1996 Crossing Lines: Formations of Australian 
Culture, Proceedings of the Association for the study of Australian Literature Conference, Adelaide 1995, Association for the Study of Australian Literature, Adelaide return to text

MacFarlane, E 2011 'Metaphor as contagion: Notes on the postscript of JM Coetzee's Elizabeth Costello', TEXT 15, 2 (October): http://textjournal.com.au/oct11/macfarlane.htm (accessed 15 November 2013) return to text

Macris, A 2012a 'Author's note: Love, capitalism, and the Generative mise en abyme', in A Macris Great Western Highway: a love story, University of Western Australia Publishing, Fremantle WA return to text

Macris, A 2012b Great Western Highway: a love story, University of Western Australia Publishing, Fremantle WA return to text

Macris, A 2008 'Sunday night at the movies: The Generative mise en abyme-as-socius', AUMLA: Journal of the Australasian Universities Language and Literature Association 109: 125 return to text

Soanes, C \& A Stevenson (eds) 2008 Concise Oxford English Dictionary (eleventh edition), Oxford University Press, Oxford return to text

Julian Murphy's writing on Australian art and literature can be found in Higher Arc, Exegesis and Arena. An earlier version of this piece was submitted towards a practice-based research subject at the University of Melbourne.

\section{TEXT}

Vol 18 No 1 April 2014

http://www.textjournal.com.au

General Editor: Nigel Krauth. Editors: Kevin Brophy \& Enza Gandolfo text@textjournal.com.au 